\title{
Міжнародна трудова міграція українців в умовах воєнного конфлікту на сході країни
}

\section{Гоць А. А., Луганський національний університет імені Тараса Шевченка}

Проведено аналіз міграційних процесів в Україні, зокрема приділено увагу зовнішній трудовій міграції в умовах воєнного конфлікту на сході України. Встановлено, що міграція населення є так званим «лакмусовим папером», що відображає проблеми в країні, є своєрідною реакцією на зміни у політичній та соціально-економічній сферах суспільства. Найбільше піддаються міграційним переміщенням особи, що мешкають у прикордонних регіонах Західної та Східної України. Виявлено, що дещо змінилися причини переміщень, якщо в 90-і роки причиною було тотальне безробіття та занепад країни, то сьогодні мігрантів манить кращий добробут інших держав, більш високі зарплати у порівнянні з Україною. Питання міграції для України актуалізувалось в останні роки у зв’язку з воєнним конфліктом на Донбасі, тому причинами трудової міграції жителів сходу є, перш за все, втрата житла або збереження життя родини, а також заробіток через втрату місць роботи у зв'язку з воєнними діями. Загалом українці найбільш часто обирають для виїзду такі країни, як Росія, Польща, Італія, Чехія, Іспанія тощо. Як суспільне явище трудова міграція має позитивні і негативні сторони, а його масштаби зумовлюють необхідність державного регулювання міграційними процесами. Тобто, показано що міграція на сьогодні має довгостроковий характер, заробітчани роблять все можливе, щоб не повертатися на батьківщину, особливо в умовах воєнного часу.

Ключові слова: трудовий мігрант; зовнішня трудова міграція; внутрішня трудова міграція; гібридна війна; ринок праці; працевлаштування; країни Європейського Союзу; країни-реципієнти; війна; кордон

\section{International labor migration of ukrainians in the conditions of military conflict in the east of the country}

\section{Hots A. A., Luhansk Taras Shevchenko National University}

The migration processes in Ukraine is analysed in the article, in particular the focus is on external labor migration in the context of a military conflict in the eastern Ukraine. The population migration is so-called «Litmus paper», reflecting problems in the country, also it is a kind of reaction to changes in the political and socio-economic spheres of society. It is established tha their magnitude and directions determine the stability or instability of social development. The aim of this article is to analyse the labor migration, which remains a topical issue in our country since nineties. External labor migration is understood as a type of migration that a person does to find a job, that is, moving of the working people for employing that can be permanently or temporary. The secondary analysis of data, which Ukrainian researchers got, was carried out to estimate the scale of migration. So it turned out that most exposed to migratory movement are people living in the border regions of Western and Eastern Ukraine. The reasons of displacement were changed a little. In the nineties the reason was total unemployment and the decline of the country, today migrants enjoy greater welfare of other states and higher wages compared to Ukraine. The issue of migration for Ukraine has been updated in recent years in connection with the military conflict in Donbas, therefore, the causes of labor migration of the East are, first of all, loss of housing or the saving of family life, as well as earnings due to the loss of jobs in connection with the military actions. Citizens of the region choose Russia for earning money, because of the border closeness, the lack of language barriers and the relatives live there as well. People from Donbas, who received or will receive the legal rights for staying in the EU countries are unlikely to return to Ukraine. Also that people who left for Russia will stay in this country. Many of them have got refugee status, others have managed to obtain another citizenship. And the negative moment is that the overwhelming majority of these citizens are young people - highly skilled specialists.

In general, Ukrainians often choose to leave for such countries as Russia, Poland, Italy, Czech Republic, Spain etc. As a social phenomenon labor migration has positive and negative sides, and its scale predetermines the need for state regulation of migration processes. It is proved that at present the most attractive European Union place among recipient countries is Poland. It has been shown that migration today has a long-term character, the migrant workers do their best not to return to their homeland, especially nowadays when there is a war in the country.

Keywords: labor migrant; external labor migration; internal labor migration; hybrid war; labor market; employment; European Union countries; recipient countries; illegal employment; war; border

\section{Международная трудовая миграция украинцев в условиях военного конфликта на востоке страны}

\section{Гоць А. А., Луганский национальный университет имени Тараса Шевченка}

Проведен анализ миграционных процессов в Украине, в частности уделено внимание внешний трудовой миграции в условиях военного конфликта на востоке Украины. Установлено, что миграция населения является так называемой «лакмусовой бумагой», что отражает проблемы в стране, является своеобразной реакцией на изме- 
нения в политической и социально-экономической сферах общества. Больше всего подвержены миграционным перемещением лица, проживающие в приграничных регионах Западной и Восточной Украины. Выявлено, что несколько изменились причины перемещений, если в 90-е годы причиной были тотальная безработица и упадок страны, то сегодня мигрантов манит большее благосостояние других государств, более высокие зарплаты по сравнению с Украиной. Вопрос миграции для Украины актуализировался в последние годы в связи с военным конфликтом на Донбассе, так причинами трудовой миграции жителей востока является, прежде всего, потеря жилья или сохранение жизни семьи, а также заработок из-за потери мест работы в связи с военными действиями. Украинцы наиболее часто выбирают для выезда такие страны, как Россия, Польша, Италия, Чехия, Испания и др. Показано, что как общественное явление трудовая миграция имеет положительные и отрицательные стороны.

Ключевые слова: трудовой мигрант; внешняя трудовая миграция; внутренняя трудовая миграция; гибридная война; рынок труда; трудоустройство; страны Европейского Союза; страны-реципиенты; война; граница

\section{Постановка проблеми.}

$\mathrm{M}$ іграція населення є невід’ємною частиною глобалізації, яка може бути охарактеризована як процес кількісного зростання та інтенсифікації політичних, економічних, соціальних, правових, культурних зв'язків та стосунків держав світу, усе більшої інтеграції людства [16].

Після набуття Україною незалежності одним зі здобутків демократизації суспільного життя стало зняття обмежень на перетин державного кордону, забезпечення вільного пересування громадян. Якщо в минулих століттях в ізольованій від світу країні закордонні поїздки були привілеєм небагатьох обраних, то в дев'яності роки минулого століття вони стали доступними пересічним громадянам. Через економічні проблеми в країні потоки наших співвітчизників шукали місця заробітку за кордоном. Останніми роками, коли частину України охопила війна, яку сьогодні називають «гібридною», 3'явились нові хвилі міграційних потоків людей, через що тема міграційних переміщень стала вкрай актуальною та насущною. Оскільки найбільш чутливим індикатором масової поведінки населення виступають міграційні рухи, які $є$ характерною реакцією на зміни у політичній та соціально-економічній сферах суспільства. Їх масштаби та напрями визначають стабільність чи нестабільність суспільного розвитку. В умовах воєнного конфлікту та нестабільної економіки Україна продовжує називатися країною-експортером робочої сили.

Аналіз досліджень і публікацій.

Питання трудової міграції аналізуються у працях таких науковців, як I. Прибиткова, О. Хомра, О. Малиновська, О. Позняк, Е. Лібанова, М. Шульга, Д. Коулмен, У. Томас, Ф. Знанецький, Р. Парк, Р. Макензі, Р. Мертон, П. Штопмка [18], Г. Беккер [1] та ін.

Метою даної статті $€$ аналіз зовнішньої трудової міграції в Україні в умовах воєнного конфлікту на Донбасі.

Виклад основного матеріалу.

Під трудовою міграцією слід розуміти переміщення у просторі, що здійснюються індивідами 3 метою підвищення рівня життя на основі більш вигідного використання власної робочої сили без зміни постійного місця проживання. Оскільки трудова міграція може виступати як початковий етап постійного переселення, ці процеси треба розглядати як два різновиди єдиного цілого - міграційної мобільності населення. На відміну від стаціонарної міграції, для цього виду міграції властиве збереження постійного зв'язку мігранта зі своєю родиною як в інформаційно-особистісних формах, так і в економічних [7].

У науковому дискурсі поряд 3 іншими теоріями виокремлюється теорія соціальних змін, автори якої, Я. Щепаньський [19], П. Штомпка [18], вказують на те, що можна розглядати міграційні процеси як атрибут соціальної реальності, як однорідні серії актів соціальної взаємодії, що призводять до змін соціально-функціонального та соціально-структурного характеру, і таким чином дослідити та більш повно інтерпретувати соціальні функції міграцій.

Однією 3 основних рис міграції $€$ перетин адміністративного кордону території (країни, області, населеного пункту тощо). На цих засадах виділяють, насамперед, зовнішню міграцію (еміграцію та імміграцію) та внутрішню міграцію. Зовнішня міграція населення пов'язана 3 перетином державного кордону і одержала назву міжнародної (міждержавної) міграції населення. Внутрішня міграція $є$ часткою міжпоселенських переміщень населення в країні.

Зовнішня міграція громадян України є комплексним процесом, який включає низку складових, основними 3 яких у період незалежності $€$ : стаціонарна міграція, яка пов'язана зі зміною офіційного місця проживання і реєструється державною статистикою; трудова міграція, пов'язана 3 виїздом на роботу за кордон без зміни місця проживання; човникова торгівля - поїздки за кордон 3 метою торгівлі (продажу або закупівлі товарів); вимушена міграція 3 окупованих територій та зони бойових дії [12]. Згідно зі ст. 1 Закону України «Про зовнішню трудову міграцію», «зовнішня трудова міграція - переміщення громадян України, пов'язане 3 перетинанням державного кордону, з метою здійснення оплачуваної діяльності в державі перебування» [4].

Серед характерних закономірностей сучасної міжнародної (міждержавної) міграції населення головну роль відіграє трудова міграція. Міжнародна трудова міграція - це виїзд населення за кордон 3 метою отримання роботи без зміни постійного місця проживання. Основними фактора- 
ми такої міграції є: безробіття, відносно низький рівень розвитку економіки i, як наслідок, низький рівень життя населення.

За статистикою, яку наводять демографи, на заробітки за кордон за останні 20 років виїхало від 7 до 15\% економічно активних громадян. Певний відсоток із них залишився за кордоном назавжди, інша частина - продовжує працювати й сподівається повернутися в Україну з кращими економічними можливостями. Найбільша ж частина українців їде за кордон на сезонні заробітки [14]. За дослідженням GFK тільки за 2015 рік офіційно мігрувало 500000 людей, проте не всі виїжджають офіційно за трудовими візами, відповідно, реальна цифра може бути вищою на 40\% [17].

Серед українців за останні три роки збільшився відсоток тих, хто не сподівається на покращення економічного клімату всередині країни. Так, згідно 3 опитуванням у квітні 2016 року соціологами Інституту Горшеніна, понад 40\% економічно активних українців віком від 18 до 29 років готові виїхати з України заради більш оплачуваної роботи та кар'єрних перспектив [14].

Згідно з опитуванням КМІС [5] практично $30 \%$ українців бажає поїхати з України, з них 55\% - молоді люди віком від 18 до 29 років; 44\% - від 30 до 39 років; 33\% - 40-50-ти річні особи. В основному це мешканці маленьких міст - $34,5 \%$ iз числа тих, хто хоче виїхати з території України [5].

Якщо подивитись на соціальний портрет мігранта, то можна виокремити два основних типи осіб, де простежується гендерний аспект. Перший - це особи, які не мають кваліфікації, не змогли знайти застосування собі в своєму місті, не особливо цілеспрямовані, однак у яких $€$ необхідність забезпечувати сім'ю. В основному це чоловіки, які їдуть працювати будівельниками в РФ. Інші - вкрай цілеспрямовані, працьовиті, «націлені на результат», ті, хто знає, чого хоче від життя. Прикладом можуть бути жінки, які бажають вийти заміж, обираючи такі країни, як ОАЕ тощо.

Незважаючи на певні розходження щодо масштабів трудової еміграції, всі джерела одностайні 3 приводу основних країн призначення українських трудових мігрантів: Росія, Польща, Італія, Чехія, Іспанія тощо [9]. Найактивніше виїжджають за кордон на заробіток жителі прикордонних регіонів, а саме Західна Україна аж до Хмельницької області та Схід.

Ситуація 3 жителями окупованої території України дещо відрізняється від інших. Тікаючи від війни, громадяни почали активно перетинати кордон та в умовах, коли воєнний конфлікт перейшов у хронічну форму, люди почали асимілюватися за кордоном. Міграційні служби переповненні нашими співвітчизниками, які намагаються узаконити своє місцезнаходження за кордоном, багато хто не боїться зміни громадянства. Негативна ситуація в тому, що більшість із таких людей - це висококваліфіковані спеціалісти, яких залюбки приймають та надають легальний спосіб знаходження на території Росії, Польщі, Америки тощо. Відмінність сьогоденної міграції громадян зі Сходу в тому, що вони не просто їдуть заробити кошти і повернутися, а роблять все можливе, щоб залишитись за кордоном та перевести туди всю свою родину.

Внаслідок географічної близькості, родинних зв'язків мешканців Донецької та Луганської областей значна частина вимушених мігрантів із зони конфлікту на Сході країни виїхала до Росії. За даними Федеральної міграційної служби РФ у 2015 р. за різних причин на території Росії було зареєстровано 2,5 млн. громадян України, або майже на мільйон більше ніж на 1 січня 2014 р. На кінець 2015 р. на обліку перебували 273 громадянина України, яким було надано статус біженця, i 311 тис. тих, які користувалися тимчасовим притулком [6]. Це тільки ті, хто зміг оформити документи, а багато хто це зробити не може. Взагалі, аналізуючи публікації в 3МI, можна стверджувати, що маючи кваліфікацію, а тим більше дипломи кандидата і вище можна без проблем отримати дозвіл на проживання в РФ, чим і користуються ті, хто втратив надію повернутися додому.

Г. Беккер стверджував, що міграція робочої сили $\epsilon$ результатом впливу низки об'єктивних чинників, таких як: відмінність між чисельністю населення та рівнем його життя у розвинених країнах, порівнюючи з третіми країнами; зниженням адміністративних та інших бар'єрів на шляху мігрантів у зв'язку з розвитком процесів глобалізації; необхідність покриття дефіциту, викликаного низьким рівнем народжуваності на ринку праці розвинутих країн за рахунок молоді з-за кордону [1].

Головними причинами можливої еміграції в грудні 2016 українці назвали пропозицію прибуткової роботи (28\%) і збройний конфлікт $(27 \%)$. Далі йдуть економічні проблеми в країні (19\%) і сімейні обставини (18\%). Замикають список згадуваних причин можливої еміграції відсутність умов для самореалізації (9\%) і політична нестабільність (7\%). Третина українців (29\%) заявили, що ніякі обставини не змусять назавжди покинути країну [10]. Основною причиною стає різниця у рівні заробітної плати. Наприклад, інженер-електрик в Україні отримує від 6000 до 12000 грн., тоді як в Німеччині 60 000-90 000 грн. [9]. До того ж на ринку праці України існує дисбаланс між попитом та пропозицією [3].

Заробітки мігрантів, які є як мінімум у три рази вищими, ніж в Україні, мають і позитивні наслідки. По-перше, заробітчани отримують роботу, по-друге, зменшується напруга на вітчизняному ринку праці, і по-третє, вони здійснюють перекази зароблених коштів своїм родичам в економіку України. За даними НБУ у I кварталі 2017 року загальний обсяг приватних грошових переказів із-за 
кордону склав 1317 млн. дол. США, що на 5,3\% більше ніж за I квартал минулого року. Приватні грошові перекази у 2016 році становили 5,8\% до
ВВП, проти 5,7\% роком раніше [8]. Надходження $70 \%$ усіх переказів в Україну було забезпечено 3 10 країн (див. рис. 1).

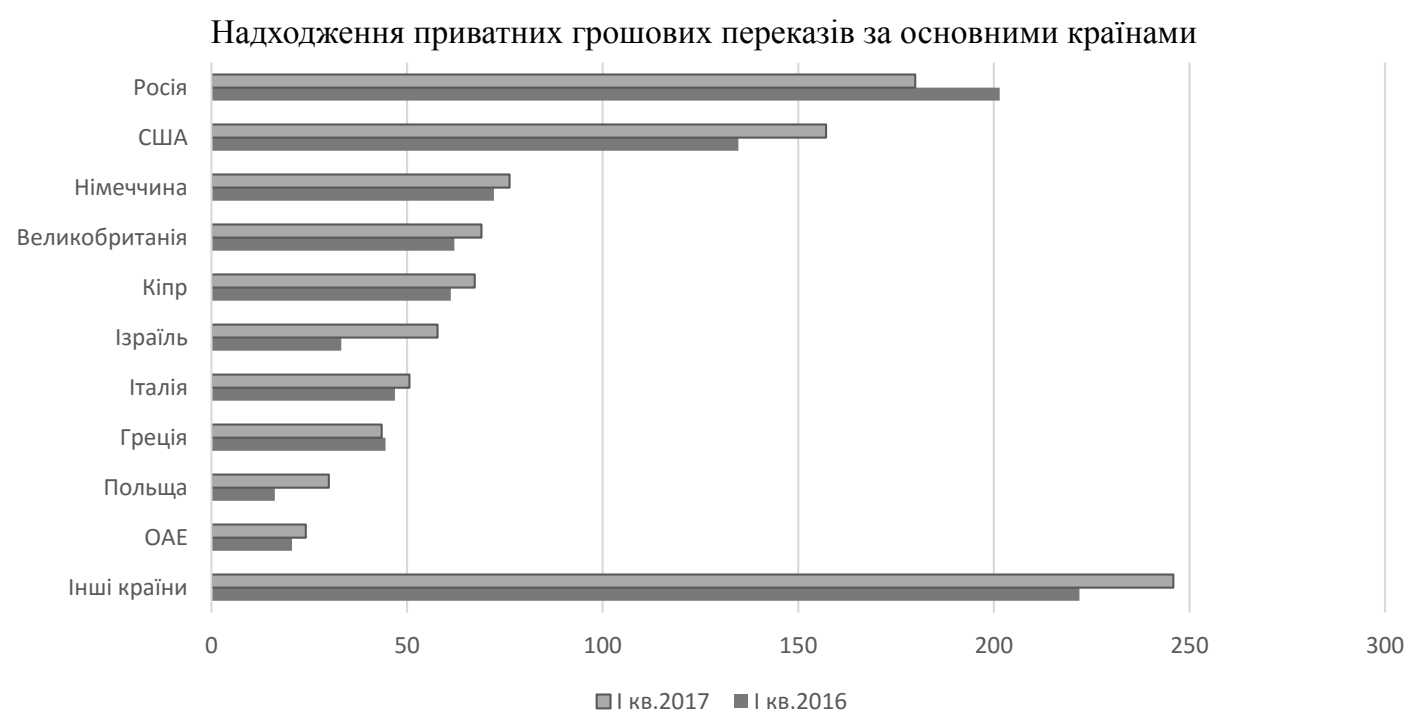

Puc. 1. Надходження приватних грошових переказів за основними країнами.

Росія залишається лідером за обсягами грошових переказів в Україну, але починаючи з 2014 року їх обсяги почали зменшуватися та в 2016 році вони знизилися порівняно 3 попереднім роком на 15, 6\% . Різке скорочення обсягів грошових переказів із Росії у IV кварталі 2016 року було спричинено рішенням Ради національної безпеки і оборони України від 16 вересня 2016 року про застосування строком на один рік обмежувальних заходів до шести платіжних організацій міжнародних платіжних систем, створених резидентами Росії [9]. Перекази з Росії обумовлені не стільки трудовою міграцією, скільки тісними сімейними зв'язками населення. Перекази із США та Німеччини хоча частково і пов'язані з трудовою міграцією, проте частково є наслідком численної етнічної еміграції з України до цих країн (євреї, німці). Однозначно пов'язані з трудовою міграцією перекази з Італії, а також Греції [15].

На сьогодні основними сферами, де зайняті працівники-мігранти є: будівництво, сільське господарство (збирання врожаю), домашнє господарство (прибирання домівки, готування їжі, доглядання дітей та немічних людей похилого віку), сфера торгівлі та сервісу. Роботи в сфері будівництва виконують практично тільки чоловіки, у сільському господарстві серед працівників-мігрантів існує приблизний гендерний паритет, а праця у домашньому господарстві та сфері сервісу $є$ прерогативою жінок.

Як суспільне явище трудова міграція має позитивні і негативні сторони, а його масштаби зумовлюють необхідність державного регулювання міграційними процесами. Загалом виділяють наступні негативні наслідки трудової міграції: виїжджає частина трудового потенціалу, в тому числі висококваліфіковані працівники, які згодом втрачають свої професійні навики, оскільки за кордоном виконувана ними робота часто носить примітивний та непрестижний характер; морально-психологічний аспект має різносторонній вплив: 3 одного боку - розпад сімей, проблема соціального «сирітства», 3 іншого - працюючи на чужині, заробітчани втрачають власне здоров'я, не отримуючи при цьому кваліфіковану медичну допомогу; зниження народжуваності у молодих сім'ях; зростання цін на товари і послуги на внутрішньому ринку, зокрема на житло, при існуючій низькій купівельній спроможності основної маси населення; загальна зневіра, втрата національної самосвідомості, набуття чужих звичаїв та невластивого менталітету [11, с. 45]; нелегальна трудова міграція не здійснює відрахувань до пенсійного та соціального фондів [15].

Щодо позитивних наслідків трудової міграції можна перерахувати такі: сприяння інтеграції України до світового ринку праці; зменшення соціальної напруги та навантаження на ринок праці, зокрема зниження рівня безробіття; надходження коштів в країну; можливість матеріального утримання на Батьківщині сімей; розвиток малого бізнесу за рахунок залучених коштів від «човникової» торгівлі; розширення світогляду, набуття свідомості та розуміння реальних умов ринкової економіки розвинутих країн, вивчення іноземних мов [2; 19]; можливість реалізувати свої здібності.

\section{Висновки.}

Iз вищевикладеного можна зробити висновки, що проблема зовнішніх трудових міграцій населення $є$ вельми актуальною для України, яка 
продовжує залишатися країною-експортером робочої сили, особливо у зв'язку з складною ситуацією на Донбасі. Головними причинами можливої еміграції українці назвали пропозицію прибуткової роботи і збройний конфлікт. Далі йдуть економічні проблеми в країні та сімейні обставини. Замикають список згадуваних причин можливої еміграції відсутність умов для самореалізації i політична нестабільність. На даний момент найбільший вплив на подальшу динаміку і географічну спрямованість міграції матиме такий фактор, як політична ситуація в країні та економічне піднесення. Міграція жителів Донбасу має вимушений характер в умовах «гібридної» війни.

\section{БІБІЛІОГРАФІЧНІ ПОСИЛАННЯ}

1. Becker G. Economics of Life: From Baseball to Affirmative Action to Immigration, How Real-World Issues Affect Our Everyday Life / G. Becker. - New York: McGraw-Hill, 1997. - Режим доступу: http://missoulatattoos.com/296867gary-s-becker-online.html

2. Гнибіденко І. Проблеми трудової міграції в Україні та їх вирішення / І. Гнибіденко // Економіка України. - 2005. - № 4. - С. 19-22.

3. Гоць А. А. Ринок освітніх послуг: проблеми функціонування в Україні // Economy and education: modern tendencies. - Opole, 2017. - C. 128-133.

4. Про зовнішню трудову міграцію: Закон України // Відомості Верховної Ради. - 2015. - № 49-50. - Ст. 463.2.

5. Мостовая Ю. Кровотечение. Почему украинцы покидат страну / Ю. Мостовая, С. Рахманин // Зеркало недели. - 2017. - Режим доступа: https://zn.ua/project/emigration/

6. Міграція в Україні: факти і цифри. - Київ: Міжнародна організація з міграції. Представництво в Україні, 2016.

- Режим доступу: http://www.iom.org.ua/sites/default/files/ff_ukr_21_10_press.pdf

7..Населення України. Трудова еміграція в Україні. - Київ: Ін-т демографії та соціальних досліджень ім. М.В. Птухи НАН України, 2010. - 233 с.

8. Огляд приватних грошових переказів в Україну в 2016 році / Управління статистики зовнішнього сектору Департаменту статистики та звітності Національного банку. - Режим доступу: https://bank.gov.ua/doccatalog/ document?id=19208358

9. Офіційний сайт Державної служби статистики України. - Режим доступу: http://www.ukrstat.org.ua.

10. Перспективні українці все частіше виїжджають за кордон: статистика. - Режим доступу: http://svitua.com.ua/ news/201701/2236-perspektyvni-ukrayinci-dedali-chastishe-vyyizhdzhayut

11. Позняк О. Групові міграції в Україні: сучасний стан, проблеми, перспективи / О. Позняк // Економічний часопис. - 2004. - № 2. - С. 34-48.

12. Позняк О. Зовнішня міграція громадян України за роки незалежності / О. Позняк // Агора. - 2016. - № 17. - С. 49-54. - Режим доступу: http://kennankyiv.org/wp-content/uploads/2016/12/Pozniak.pdf

13. Приватні грошові перекази у I кварталі 2017 року // Громадська спілка «Економічний дискусійний клуб», 2017. - Режим доступу: http://edclub.com.ua/analityka/pryvatni-groshovi-perekazy-u-i-kvartali-2017-roku

14. Радчук О. Україна переживає бум внутрішньої та зовнішньої трудової міграції / О. Радчук // Слово і Діло. - 2016. - Режим доступу: https://www.slovoidilo.ua/2016/06/15/kolonka/aleksandr-radchuk/ekonomika/u-pastcziekonomichnoyi-bezvyxodi-novi-ryzyky-trudovoyi-mihracziyi-dlya-ukrayiny.

15. Сирочук Н. А. Міжнародна трудова міграція українців до країн Європейського Союзу: фактори впливу / Н. А. Сирочук // Економічний вісник Національного технічного університету України «Київський політехнічний інститут». - 2014. - № 11. - С. 110-118.

16. Кононов І. Ф. Теоретична соціологія. Курс лекцій: підручник для студентів вищих навчальних закладів / I. Ф. Кононов. - Луганськ: Вид-во ДЗ «ЛНУ імені Тараса Шевченка», 2013. - Т. 1. - 576 с.

17. Абрамова О. Трудова міграція: загрози та можливості. - 2015. - Режим доступу: https://prohr.rabota.ua/trudovamigratsiya/

18. Штомпка П. Социология социальных изменений: пер. с польск. / П. Штомпка; под ред. В. А. Ядова. - М.: Аспект Пресс, 1996. - 416 с.

19. Щепаньский Я. Элементарные понятия социологии / Я. Щепаньский; общ. ред. и послесл. А. М. Румянцева. - М.: Прогресс, 1969. - 240 с.

\section{REFERENCES}

1. Becker, G. (1997). Economics of Life: From Baseball to Affirmative Action to Immigration, How Real-World Issues Affect Our Everyday Life. New York: McGraw-Hill. Retrieved from: http://missoulatattoos.com/296867-gary-s-beckeronline.html

2. Gnybidenko, I. (2005). Problemy trudovoi mihratsii v Ukraini ta yikh vyrishennia [Problems of labor migration in Ukraine and their solution]. Economy of Ukraine, 4, 19-22 [in Ukrainian].

3. Gots, A.A. (2017). Rynok osvitnikh posluh: problemy funktsionuvannia v Ukraini [Educational Services Market: Problems of Functioning in Ukraine]. Economy and education: modern tendencies. Opole, 128-133 [in Ukrainian].

4. Pro zovnishniu trudovu mihratsiiu: Zakon Ukrainy [On Foreign Labor Migration: The Law of Ukraine]. (2015). Bulletin of the Verkhovna Rada, 49-50, Art. 463.2 [in Ukrainian]. 
5. Mostovaia, Yu., \& Rakhmanin, S. (2017). Krovotechenye. Pochemu ukrayntsu pokydat stranu [Bleeding. Why Ukrainians leave the country]. Mirror of the week. Retrieved from: https://zn.ua/project/emigration/ [in Russian].

6. Mihratsiia v Ukraini: fakty i tsyfry [Migration in Ukraine: Facts and Figures] (2016). Kyiv: International Organization for Migration. Representation in Ukraine. Retrieved from: http://www.iom.org.ua/sites/default/files/ff_ukr_21_10_press. pdf [in Ukrainian].

7. Naselennia Ukrainy. Trudova emihratsiia v Ukraini [Population of Ukraine. Labor emigration in Ukraine]. (2010). Kyiv: Institute of Demography and Social Studies M.V. Studs of the National Academy of Sciences of Ukraine [in Ukrainian].

8. Ohliad pryvatnykh hroshovykh perekaziv v Ukrainu v 2016 rotsi [Overview of Private Money Transfers to Ukraine in 2016]. Department of Statistics of the External Sector of the Department of Statistics and Reporting of the National Bank. Retrieved from: https://bank.gov.ua/doccatalog/document?id=19208358 [in Ukrainian].

9. Ofitsiinyi sait Derzhavnoi sluzhby statystyky Ukrainy [Official site of the State Statistics Service of Ukraine]. Retrieved from: http://www.ukrstat.org.ua. [in Ukrainian].

10. Perspektyvni ukraintsi vse chastishe vyizhdzhaiut za kordon: statystyka [Promising Ukrainians are increasingly moving abroad: statistics]. Retrieved from: http://svitua.com.ua/news/201701/2236-perspektyvni-ukrayinci-dedalichastishe-vyyizhdzhayut [in Ukrainian].

11. Pozniak, O. (2004). Hrupovi mihratsii v Ukraini: suchasnyi stan, problemy, perspektyvy [Group migration in Ukraine: the current state, problems, prospects]. Economic Journal, 2, 34-48 [in Ukrainian].

12. Pozniak, O. (2016). Zovnishnia mihratsiia hromadian Ukrainy za roky nezalezhnosti [Foreign migration of Ukrainian citizens during the years of independence]. Agora, 17, 49-54 [in Ukrainian].

13. Pryvatni hroshovi perekazy u I kvartali 2017 roku [Private Money Transfers in the 1st quarter of 2017]. (2017). Public Union «Economic Discussion Club». Retrieved from: http://edclub.com.ua/analityka/pryvatni-groshovi-perekazyu-i-kkvartali-2017-roku [in Ukrainian].

14. Radchuk, O. (2016). Ukraina perezhyvaie bum vnutrishnoi ta zovnishnoi trudovoi mihratsii [Ukraine is experiencing a boom in internal and external labor migration]. Word and Act. Retrieved from: https://www.slovoidilo.ua/06/06/15/ kolonka/aleksandr-radchuk/ekonomika/u-pastczi-ekonomichnoyi-bezvyxodi-novi-ryzyky-trudovoyi-mihracziyi-dlyaukrayiny [in Ukrainian].

15. Syrochuk, N.A. (2014). Mizhnarodna trudova mihratsiia ukraintsiv do krain Yevropeiskoho Soiuzu: faktory vplyvu [International labor migration of Ukrainians to the countries of the European Union: factors of influence]. Economic Bulletin of the National Technical University of Ukraine «Kyiv Polytechnic Institute», 11, 110-118 [in Ukrainian].

16. Kononov, I.F. (2013). Teoretychna sotsiolohiia. Kurs lektsii: pidruchnyk dlia studentiv vyshchykh navchalnykh zakladiv [Theoretical Sociology. Course of lectures: textbook for students of higher educational institutions]. (Vol. 1). Lugansk: View of DZ «Taras Shevchenko LNU» [in Ukrainian].

17. Abramova, O. (2015). Trudova mihratsiia: zahrozy ta mozhlyvosti [Labor Migration: Threats and Opportunities]. Retrieved from: https://prohr.rabota.ua/trudova-migratsiya/ [in Ukrainian].

18. Shtompka, P. (1996). Sociologija social'nyh izmenenij [Sociology of social change]. V.A. Yadov (Eds.). Moscow: Aspect Press [in Russian].

19. Shhepan'skij, Ja. (1969). Jelementarnye ponjatija sociologii [Elementary notions of sociology]. A.M. Rumyantsev (Eds.). Moscow: Progress [in Russian].

\section{Гоць Аліна Анатоліївна}

кандидат соціологічних наук, доцент кафедри філософії та соціології

Луганський національний університет імені Тараса Шевченка

92703, м. Старобільськ, вул.. Гоголя 1

\section{Gots Alina}

candidate of Sociological Sciences, docent Department of Philosophy and Sociology

Lugansk Taras Shevchenko National University

1, Gogolya St., 92703, Starobilsk, Ukraine

ORCID: 0000-0001-9675-8032_Email: ukolova_alina@ukr.net

Цитування: Гоць А. А. Міжнародна трудова міграція українців в умовах воєнного конфлікту на сході країни / А. А. Гоць // Науково-теоретичний альманах «Грані». - 2018. - Т. 21. - № 2. - С. 6-11

Citation: Hots A. A. (2018). Mizhnarodna trudova mihratsiia ukraintsiv v umovakh voiennoho konfliktu na skhodi krainy [International labor migration of ukrainians in the conditions of military conflict in the east of the country]. Scientific and theoretical almanac «Grani», 21(2), 6-11. 